\title{
CENTRAL ASIAN DUST EXPERIMENT (CADEX): MULTIWAVELENGTH POLARIZATION RAMAN LIDAR OBSERVATIONS IN TAJIKISTAN
}

\author{
Julian Hofer ${ }^{1 *}$, Dietrich Althausen ${ }^{1}$, Sabur F. Abdullaev ${ }^{2}$, Ronny Engelmann ${ }^{1}$, Holger Baars ${ }^{1}$ \\ ${ }^{1}$ Leibniz Institute for Tropospheric Research, Leipzig, Germany, *Email: hofer@tropos.de \\ ${ }^{2}$ Physical Technical Institute of the Academy of Sciences of Tajikistan, Dushanbe, Tajikistan
}

\begin{abstract}
For the first time lidar measurements of vertical aerosol profiles are conducted in Tajikistan/ Central Asia. These measurements just started on March $17^{\text {th }}, 2015$. They are performed within the Central Asian Dust Experiment (CADEX) in Dushanbe and they will last at least one year. The deployed system for these observations is an updated version of the multiwavelength polarization Raman lidar Polly ${ }^{\mathrm{XT}}$. Vertical profiles of the backscatter coefficient, the extinction coefficient, and the particle depolarization ratio are measured by this instrument. A first and preliminary measurement example of an aerosol layer over Dushanbe is shown.
\end{abstract}

\section{INTRODUCTION}

Tajikistan (Fig. 1) lies in the global dust belt in close proximity of some major dust sources like the Taklimakan desert, the Aralkum desert of the desiccating Aral Sea, the Kyzylkum and Karakum deserts east of the Caspian Sea, and the Iranian Dasht-e-Kavir and Dasht-e-Lut deserts. Therefore Tajikistan is frequently affected by severe dust events. Furthermore, Central Asia and especially Tajikistan are highly affected by climate change. For example, dramatic glacier shrinking took place in the last decades [1], which has also an effect on the water resources of Tajikistan and the whole Central Asian area, since trans-regionally important rivers as Amu Darya and Syr Darya are fed by glacier meltwater.

Aerosol observations in Tajikistan are therefore highly important to understand regional and global transport of mineral dust and its effects on radiation budget, cloud formation etc.

Up to now, only few experiments were performed to characterize the aerosol over Central Asia. So, a joint Soviet-American research group did dust research in Tajikistan in 1989 [2]. They characterized the chemical and physical properties of mineral dust collected in 2 dust storms [3, 4]. During these dust storms in 1989 optical depths of up to 3.5 (at $550 \mathrm{~nm}$ ) were measured. Furthermore a few vertical profiles of the dust distribution were measured by aircraft [5]. They found well mixed dust aerosols up to a height of $3 \mathrm{~km}$.

Nevertheless, the knowledge of the vertical aerosol distribution over Tajikistan and especially the transport of mineral dust over Central Asia is still insufficient. Therefore CADEX aims to provide long-term data on vertical profiles of the backscatter coefficient, the extinction coefficient, and the particle depolarization ratio.

\section{FIELD SITE AND INSTRUMENTATION}

The measurement site is located in an urban area on a slightly elevated hill near the Physical Technical Institute of the Academy of Science of Tajikistan in Dushanbe. Its coordinates are $38^{\circ} 33^{\prime} 34^{\prime \prime} \mathrm{N}, 68^{\circ} 51^{\prime} 22^{\prime \prime} \mathrm{E}$, and its altitude is 864 m a.s.l..

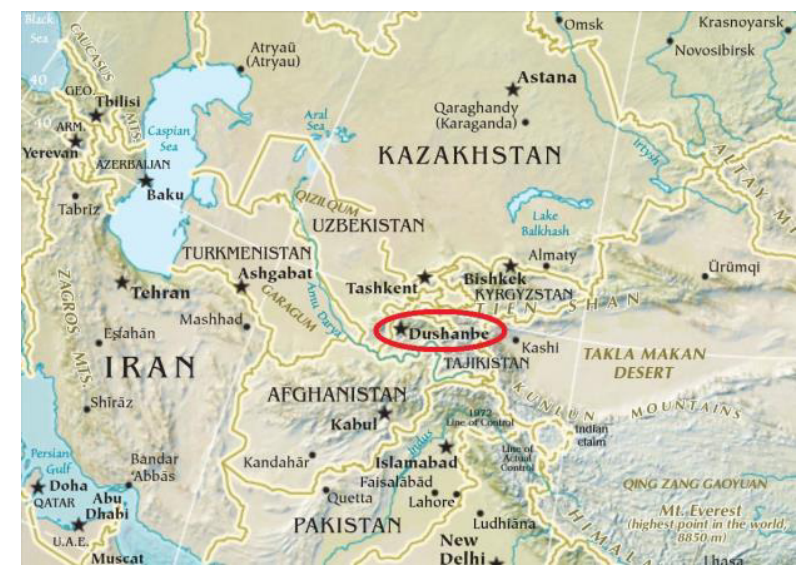

Fig. 1: Physical map of Central Asia with Dushanbe/Tajikistan (red circle). (The World Factbook 2013-14. Washington, DC: Central Intelligence Agency, 2013)

The updated version of the multiwavelength polarization Raman lidar Polly ${ }^{\mathrm{XT}}[6$, original design] is used for the lidar measurements. The 
last improvements were the installation of an additional depolarization channel at $355 \mathrm{~nm}$ for this campaign (Fig. 2) and the change of most of the electronic components to the current Polly ${ }^{\mathrm{XT}}$ systems standard parts to ensure higher counting rates (see contribution Engelmann et al. [7] at this conference). All Polly ${ }^{\mathrm{XT}}$ systems contain a laser that emits light at $355 \mathrm{~nm}, 532 \mathrm{~nm}$, and $1064 \mathrm{~nm}$. The receiver of the used system has 8 channels. With this system, vertical profiles of the backscatter coefficient are determined for all three emitted wavelengths. The channels at $387 \mathrm{~nm}$, $607 \mathrm{~nm}$, and $407 \mathrm{~nm}$ allow to detect Raman scattering at night time to determine extinction coefficient and water vapor profiles. Another two channels are installed to detect cross-polarized light at $355 \mathrm{~nm}$ and $532 \mathrm{~nm}$. This allows to measure the particle depolarization ratio at these wavelengths. The system has a vertical resolution of $7.5 \mathrm{~m}$ and temporal resolution of $30 \mathrm{~s}$.

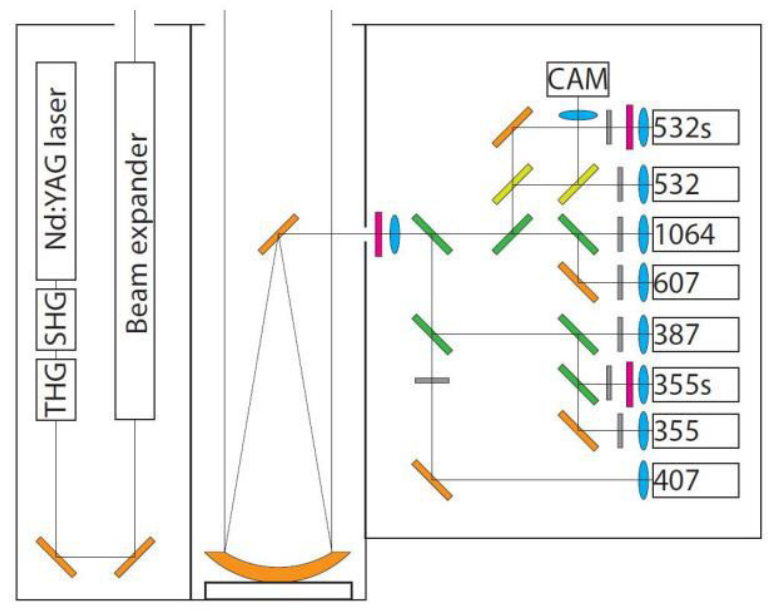

Fig. 2: Scheme of Polly ${ }^{\mathrm{XT}} .1064 \mathrm{~nm}$ Nd:YAG laser with second (SHG) and third harmonic generation (THG). Orange: Mirrors, including parabolic $30 \mathrm{~cm}$ main mirror. Blue: Lenses. Green: Dichroic beam splitters. Yellow: Nonpolarizing $50 \%$ beam splitters. Magenta: Polarizers. Grey: Neutral density filters. Numbers: Photomultiplier tubes for the different wavelengths. CAM: Camera.

Additionally, a CIMEL sun photometer from the AERONET station in Dushanbe is collocated with the Polly ${ }^{\mathrm{XT}}$ lidar to measure the aerosol optical depth and retrieve further particle properties, like size distribution, fine and coarse mode fraction.
There are also devices measuring ground level aerosols at the measurement site in Dushanbe. A Digitel DHA-80 High Volume Sampler is collecting PM10 particulates on quartz fiber filters for subsequent chemical analysis. A Grimm Environmental Dust Monitor EDM-180 is measuring particle size distribution of ground level aerosols without any initial cut off size.

Later, simulations with the regional dust model COSMO-MUSCAT [8] will be performed to access the transport and radiative effects of the dust during the time of the field campaign. The properties measured with the Polly ${ }^{\mathrm{XT}}$ serve as input parameters for the model.

\section{FIRST MEASUREMENTS}

An example of one of the first measurements during CADEX is shown in Fig. 3. The temporal evolution of the range-corrected signal at $1064 \mathrm{~nm}$ on March $19^{\text {th }}, 2015$ reveals a lofted aerosol layer, located between the planetary boundary layer and the high-level cirrus clouds. The layer is settling down from about $6 \mathrm{~km}$ to about $4.5 \mathrm{~km}$ from 00:04 to 06:00 UTC. Between 03:00 and 04:00 UTC a cirrus cloud has formed in the altitude of about $6 \mathrm{~km}$ where the layer was located before.

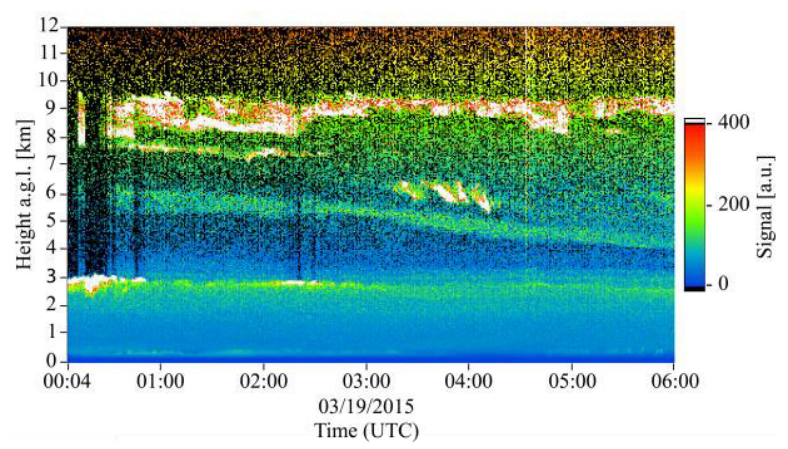

Fig. 3: Temporal evolution of the range-corrected signal at $1064 \mathrm{~nm}$ on March 19 ${ }^{\text {th }}, 2015$.

HYSPLIT $[9,10]$ back trajectories indicate that the air, carrying this aerosol layer at $6 \mathrm{~km}$ height, was transported over the Middle East to Tajikistan (Fig. 4). Despite being transported along the global dust belt the air did not reach into the planetary boundary layer.

Fig. 5 shows vertical profiles of the backscatter coefficient (a), the extinction coefficient (b), the depolarization ratio (c) and the lidar ratio (d) averaged between 00:50 and 01:05 UTC on 
March $19^{\text {th }}$, 2015. The analysis was conducted with the Raman method [11]. The depolarization ratio was calculated based on the internal depolarization calibration which is automatically

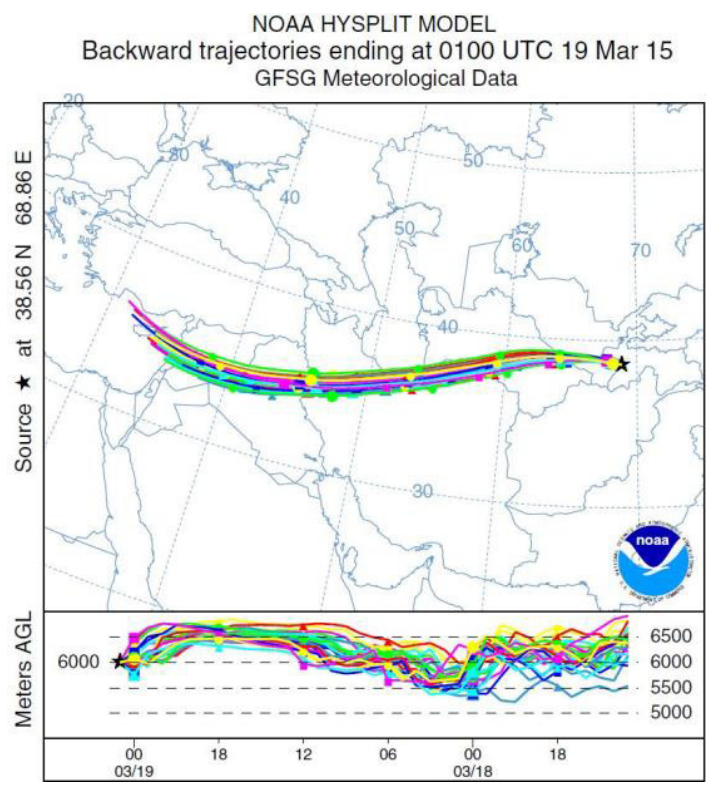

Fig. 4: HYSPLIT ensemble backward trajectories arriving on $6 \mathrm{~km}$ over Dushanbe at 01:00 UTC on March $19^{\text {th }}, 2015$.
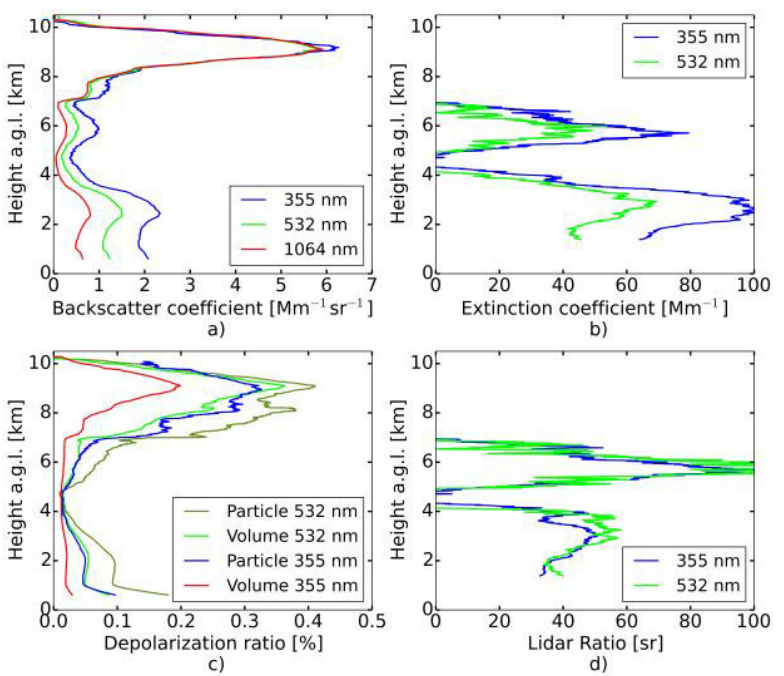

Fig. 5: Averaged profiles from 0050 to 0105 UTC on March $19^{\text {th }}$, 2015, of a) backscatter coefficients for $355 \mathrm{~nm}, 532 \mathrm{~nm}$, and $1064 \mathrm{~nm}$, b) extinction coefficients for $355 \mathrm{~nm}$ and $532 \mathrm{~nm}$, c) volume and particle depolarization ratios for $355 \mathrm{~nm}$ and $532 \mathrm{~nm}$, and d) lidar ratios for $355 \mathrm{~nm}$ and 532 $\mathrm{nm}$. The backscatter coefficient and the depolarization ratio are smoothed over 161, the extinction coefficient and the lidar ratio over 231 vertical bins.
Performed by the system three times a day [12]. Low signal-to-noise ratios did not allow the calculation of extinction coefficients and lidar ratios above $7 \mathrm{~km}$. The lofted aerosol layer between about 5 to $6 \mathrm{~km}$ depolarizes only weakly (Fig. 4c)) but has larger extinction values (Fig. $4 b)$ ). Also it shows rather large lidar ratios of $>60$ sr. So, bringing this information together leads to the conclusion that this layer is a particle layer originating mainly from pollution and/or burning processes and it is most likely not mineral dust. However, the shown data have to be considered yet as very preliminary. Ongoing overviews of the measurements in Dushanbe are available under http:\polly.rsd.tropos.de and www.tropos.de/ en/research/projects-infrastructures-technology/ research-projects/cadex-home/.

\section{OUTLOOK}

The Polly ${ }^{\mathrm{XT}}$ lidar is measuring since March $17^{\text {th }}$, 2015 in Dushanbe, Tajikistan. It is planned to operate it continuously until at least April 2016. The obtained backscatter, extinction and depolarization profiles will be used to characterize the aerosol types [e.g. 13, 14]. Analyses of HYSPLIT back trajectory clusters have indicated that the air masses arriving in Tajikistan can carry desert dust from as far as the Sahara and the Middle East. Hence we will statistically analyze the aerosol characterization and especially the measured aerosol optical properties according to the air masses' origin. Also anthropogenic pollution from local and distant sources is likely to form a complex aerosol mixture together with desert dust over Tajikistan. This needs approaches to separate optical profiles of dust from non-dust like [15]. Furthermore a separation of coarse mode and fine mode dust like [16] will be done with the performed polarization measurements.

\section{ACKNOWLEDGEMENT}

We want to thank Dr. K. W. Fomba, Dr. K. Müller, and Dr. B. Heinold from TROPOS Leipzig, and Dr. G. Schettler from GFZ Potsdam for their contributions to CADEX. Special thanks go to the Physical Technical Institute of the Academy of Sciences of Tajikistan for their collaboration and for providing the measurement site and maintaining the instrumentations. Further, we would like to thank the German Ministry of Education and Research for funding this project. 


\section{REFERENCES}

[1] Kayumov, A.: Glaciers Resources of Tajikistan in Condition of the Climate Change, State Agency for Hydrometeorology of Committee for Environmental Protection under the Government of the Republic of Tajikistan.

[2] Golitsyn, G., Gillette, D. A., 1993: Introduction: A joint Soviet-American experiment for the study of Asian desert dust and its impact on local meteorological conditions and climate. Atmos. Environ., 27(16), 2539-2544.

[3] Gomes L., Gillette D. A., 1993: A comparison of characteristics of aerosol from dust storms in Central Asia with soil-derived dust from other regions. Atmos. Environ., 27(16), 2539-25.

[4] Sokolik, I. N., Andronova, A. V., Johnson, T. C., 1993: Complex refractive index of atmospheric dust aerosols. Atmos. Environ., 27(16), 2495-2502.

[5] Pachenko, M. V., Terpugova, S. A., Bodhaine, B. A., Isakov, A. A., Sviridenkov, M. A., Sokolik, I. N., Romashova, E. V., Nazarov, B. I., Shukurov, A. K., Chistyakova, E. I., Johnson, T. C., 1993: Optical investigations of dust storms during U.S.S.R.-U.S. experiments in Tadzhikistan, 1989. Atmos. Environ., 27(16), 2503-2508.

[6] Althausen, D., Engelmann, R., Baars, H., Heese, B., Ansmann, A., Müller, D., Komppula, M., 2009: Portable Raman Lidar Polly ${ }^{\mathrm{XT}}$ for Automated Profiling of Aerosol Backscatter, Extinction, and Depolarization. J. Atmos. Oceanic Technol., 26(11), 2366-2378.

[7] Engelmann, R., Ansmann, A., Bühl, J., Heese, B., Baars, H., Althausen, D., Marinou, E., Amiridis, V., Mamouri, R., Vrekoussis, M., 2015: Observation of Arabian and Saharan dust in Cyprus with a new generation of the smart Raman lidar Polly. Proceedings of the $27^{\text {th }}$ ILRC, New York City, 2015.

[8] Heinold, B., Helmert, J., Hellmuth, O., Wolke, R., Ansmann, A., Marticorena, B., Laurent, B., and Tegen, I., 2007: Regional modeling of Saharan dust events using LM-MUSCAT: Model description and case studies. J. Geophys. Res. Atmos., 112(D11).
[9] Draxler, R. R., Rolph, G. D., 2015: HYSPLIT (HYbrid Single-Particle Lagrangian Integrated Trajectory) Model access via NOAA ARL READY Website (http://ready.arl.noaa.gov/HYSPLIT.php). NOAA Air Resources Laboratory, Silver Spring, MD.

[10] Rolph, G. D., 2015: Real-time Environmental Applications and Display sYstem (READY) Website (http://ready.arl.noaa.gov). NOAA Air Resources Laboratory, Silver Spring, MD.

[11] Ansmann, A., Wandinger, U., Riebesell, M., Weitkamp, C., Michaelis W., 1992: Independent measurement of extinction and backscatter profiles in cirrus clouds by using a combined Raman elastic-backscatter lidar. Appl Opt., 31(33), 7113-7131.

[12] Freudenthaler, V., Esselborn, M., Wiegner, M., Heese, B., Tesche, M., Ansmann, A., Müller, D., Althausen, D., Wirth, M., Fix, A., Ehret, G., Knippertz, P., Toledano, C., Gasteiger, J., Garhammer, M., Seefeldner, M. 2009: Depolarization ratio profiling at several wavelengths in pure Saharan dust during SAMUM 2006. Tellus, 61B, 165-179.

[13] Groß, S., Esselborn, M., Weinzierl, B., Wirth, M., Fix, A., Petzold, A., 2013: Aerosol classification by airborne high spectral resolution lidar observations. Atmos. Chem. Phys., 13, 24872505.

[14] Burton, S. P., Ferrare, R. A., Hostetler, C. A., Hair, J. W., Rogers, R. R., Obland, M. D., Butler, C. F., Cook, A. L., Harper, D. B., Froyd, K. D., 2012: Aerosol classification using airborne High Spectral Resolution Lidar measurements methodology and examples. Atmos. Meas. Tech., 5, 73-98.

[15] Tesche, M., Ansmann, A., Müller, D., Althausen, D., Engelmann, R., Freudenthaler, V., Groß, S., 2009: Vertically resolved separation of dust and smoke over Cape Verde by using multiwavelength Raman and polarization lidars during Saharan Mineral Dust Experiment 2008. J. Geophys. Res. - Atmos., 114(D13).

[16] Mamouri, R., Ansmann, A., 2014: Fine and coarse dust separation with polarization lidar. Atmos. Meas. Tech., 7, 3717-3735. 